\title{
ADDITIONAL DATA ON THE EPIDEMIOLOGY OF CHAGAS DISEASE IN THE MUNICIPALITY OF CAXIAS, RIO DE JANEIRO STATE, BRAZII *
}

\author{
J. Rodrigues Coura ** and Walter B. Petana ***
}

\begin{abstract}
An area believed to be an autochthonous focus for Chagas' disease was investigated in the municipality of Caxias, Rio de Janeiro State. The study included search for domestic triatomine bugs, serological test (IFT and CFT) in persons in whose house infested bugs were discovered, detailed clinical examination and xenodiagnosis test of all serologicall/ yy positive persons, and xenodiagnosis test on dogs from households in which infected triatomine bugs have been found.

Only in one of the locatities (Piranema) domestic Triatoma infestans have been discovered. some of which were infected with $\mathrm{T}$. cruzi. A small number of persons (mostly children) had a positive serological test for Chagas' disease, but in all of them the infection was clinically asymptomatic. From two dogs, belonging to a household in which serologically positive children and infected $\mathrm{T}$. infestans were discovered, $\mathbf{T}$. cruzi was isolated by xenodiagnosis.

The important epidemiological information obtained from this investigation was the discovery of domestic addaptation of $\mathrm{T}$. infestans in an area with dense population and with very low social and sanitary conditions, in a locality considered as non-endemic for the infection.
\end{abstract}

\section{INTRODUCTION}

The presence of triatomine bugs infected with $T$. cruzi in the Rio de Janeiro State was first reported by Neiva (6) in 1914, and again by Neiva and Pinto (7) in 1923. A further report on the presence of triatomine bugs in the State was furnished by Lent (5) in 1942 . In 1953 Dias et al. (4) described the findings from a serological and electrocardiographic servey for Chagas' disease among a small seg- ment of population in two districtis, and in the same year Bustamante and Gusmão (2) reported on domestic $T$. infestans in the municipalities of Rezende and Itavera. In 1971 Aragão and Souza (1) discovered domestic $T$. infestans in the municipality of Caxias. In 1971 Coura et al. (3) ciescribed a localized /focus of Chagas' disease close to the city of Rio de Janeiro, in the municipality of Caxias. Out of 33 houses searched, 18 were found infested by $T$. infestans, and in several of the insects

- This work was supported with funds from the Conselho Nacional de Pesquisas of Brazil, from the Ministry of Overseas Development, London, and from the World Health Organization.

* Professor of Tropical Medicine, Head of Departament of Preventive Medicine, Federal University of Rio de Janeiro.

-: Consultant in Medical Parasitology on secondement to the Federal University of Rio de Janeiro from the Ministry of Overseas Development, London, under the Anglo-Brazilian Agreeent on Technical Cooperation.

Submitted to publication on 2.10.1975. 
examined $T$. cruzi was found in the gut contents. The complement fixation test (CFT) for Chagas' disease, carried out on 110 persons living in the locality, was positive in six cases; theree of the serologically positive patients also had a positive xenodiagnosis test. Three of the serollogically positive persons, including one with positive xenodiagnosis, have lived in the locality all their life, which suggested an autochthonous focus for the infection. In conclusion Coura et al. (3) emphasized the need for widening the investigation to obtain a more comprehensive information on the epidemiological importance of this isolated focus of Chagas' cisease in a densely populated area with very low social, economic, and sanitary conditions.

In June 1971 a research scheme on Chagas' disease was initiated in the Department of Preventive Medicine, Federal University of Rio de Janeiro, and it was decided to start the project by investigating the epidemiology of Chagas, disease in the Caxias area in more detail.

\section{METHODS OF INVESTIGATION}

For convenience, a short account is given of the geographic and other features of the Rio de Janeiro State. The State (see map) is situated on the southern costal area of Brazil and is bordered on the north side by the Minas Gerais and Espírito Santo States, and on the south side by Sāo Paulo State; on the eastern side it faces the Atlantic Ocean. The population is estimated in the region of $9,000.000$, the capital city in Rio de Janeiro. The geographic features are variable, with numerou mountain ranges in the interior and lowland near the coast. Most of the region is covered with dense vegetation consisting of various shrubs, palm-and hardwood trees. Although the whole of the State lies within the tropics, the climate may be divided into two distinct seasons. From October until March it is hot near the coast but cooler in the elevated areas. From April to September it is warm in the lowlands, but cool to cold in the mountain ranges. Although the States is well developed industrially, a large segment of the population is engaged in agriculture and animal husbandry.
The first village investigated was Piranema, followed by the villages of Capivari and Amapa (see map). Piranema consists of about 119 houses which are scattered widely over an area of about 25 square miles. The population numbers about 800 persons and the main occupation is farming on a small scale Most of the villagers are immigrants from other parts of Brazil, and many come from areas known as endemic for Chagas' disease. The locality is about $30 \mathrm{~km}$ distance from the city of Rio de Janeiro, and was visited usually twice a week. During the rains the visits were infrequent as the roads and bush tracks were impassable for motor vehicles. Prior to the survey a mounted specimen of a triatomine bug was prepared to simulate the appearance of the insect in life. The bug was shown to members of each household visited and questions were asked to find out how many recognized the bug. The search for bugs inside houses was carried out by using pyrethrum powder which was sprayed on the walls, mainly in the sleeping quarters, and on the underside of roofs with thatch. A similar procedure was used in animal shelters and chicken pens. After about 10 minutes wait, the walls and the roof were searched with electric torches for any bugs that were driven out by the pyrethrum irritant. The captured insects were brought to the laboratory for examination for gut flagellates, and the non-infected female adult bugs were retained in the insectary for deposition of eggs for our 'clean' colony of $T$. infestans. Identical method of investigation was used in the two villages Capivari and Amapá.

All member from each household where infected triatomine bugs were discovered were subject to a serological test for Chagas' disease (IFT and CFT), and a serological survey was carried out on almost all the school children from the three villages. The blood was collected on filter paper discs and screened by indirect fluorescence test (IF'T) for $T$. cruzi antibodies. All reative sera were confirmced by the complement fixation test, and the patients were brought to our clinic for a detailed examination and for a xenodiagnosis test. A xenodiagnosis was also carried out on dogs from each household where serologically positive persons were discovered. The faeces $f r c m$ the naturally infected domes- 
tic bugs, and from all positive bugs used in the xenodiagnosis test, were - inoculated into white mice for studies on the behaviour of the parasites under experimental condition.

\section{RESULTS}

A total of 115 houses were searched in Piranema, of which $15(13.0 \%)$ were found infested by $T$. infestans. The total number of nymphs and of adult bugs captured in each house are summarized in table no. 1. In three of the houses (P-1, P-3, and $P$-15) the bugs were found infected with T. cruzi. The total number of bugs collected in these three houses and the incidence of infection with $T$. cruzi in the nymphs and in adults bugs are shown in table no. 2.

House P-1 is occupied by two adults and seven children. Four of the children were serologically positive for Chagas' disease and in three the infection was confirmed also by xenodiagnosis. Two dogs living in the same house had also a positive xenodiagnosis test (Plate I, fig. A).

In house P-3 there are two adults, husband and wife. Both had a positive serological test and from the husband $T$. cruzi was isolated by xenodiagnosis.

In house P-15 there are two adults and 11 children. In five children the serological test was positive (Plate II, fig. B), and in four the infection was also confirmed parasitologically. Five dogs from the same household were found negative by xenodiagnosis.

Detailed clinical examination of the serologically positive patients revealed no serious cardiac or other symptoms suggestive of clinical form of Chagas' disease. The behaviour of $T$. cruzi in white mice inoculated with faeces from the naturally infected bugs, and from the bugs used in xenodiagnosis test, has been described previously (8) .

In the village of Capivari, 35 dwellings were searched but no bugs were discovered and the search was abandoned. The villagers furnished the information that all the houses in this locality have been treated previously with DDT insecticide, under the malaria eradication scheme. Some of the householders claimed that, prior to the application of the insecticide, they had seen triatomine bugs in their diwelling, but since the application of the insecticide they seem to have disappeared. To verify this information a thorough search was made in the allegedly previously infested houses but no triatomines were recovered.

A similar situation as in Capivari was found in the village of Amapá, where the houses were also treated with DDT. After a thorough search in dwellings which supposed to have had domestic triatomines before the application of the insecticide no bugs were found.

The result obtained from the serological survey in school children in the three localities investigated was as follows. In Piranema 111 blood samples have been collected of which four were positive for T. cruzi antibodies. The samples were from the children from house P-15 in whom the serological test was positive previously. The 365 blood samples from Capivari and 121 from Amapá were all negative.

\section{DISCUSSION AND CONCLUSION}

The presence of $T$. infestans in the municipality of Caxias is of importance as well as of epidemiological interest, as it is the nearest locality to a large city (Rio de Janeiro), and to the sea coast, known to be penetrated and inhabited by this important vector of Chagas' disease. The high incidence of infection with $T$. cruzi in the bugs captured in houses $P-1, P-3$, and $P-15$ was no doubt due to the fact that the bugs became infected at a fast rate by feeding on the infected humans repeatedly in such circle of cohabitation. An added feature of interest was the infection with $T$. cruzi in the two dogs from house $P-1$, whilst in house P-15 none of the five dogs had a positive xenodiagnosis test although the infection rate with $T$. cruzi in the bugs from this house was very high. This may be explained on the grounds that the householder in house P-1 allowed the dogs to share the sleeping quarters with members of the family, whereas in house P-15 
the dogs were not allowed to sleep in the house.

The absence of clinical symptoms in the serologically positive patients postulates that the $T$. cruzi strain (or strains) were of a low virulence producing an asymptomatic and undetermined form of the infection.

The most important epidemiological feature obtained from this investigation was the presence of a species of triatomine bug, known as an efficient vector for Chagas' disease, in an area generally believed to be non-endemic for the infection.

\section{ACKNOWLEDGEMENTS}

We wish to thank the Conselho Nacional de Pesquisas of Brazil, the Ministry of Overseas Development in London, and to the World Health Organization for their interest, and for financial support, of these investigations. To Professor Fritz Koeberle, Faculty of Medicine, Ribeirão Preto, (U.F.S.P.), we are grateful or his histopathological evaluation on sections from organs of the infected animals. To our post-graduate studens in tropical medicine, and to the laboratory staff, we are indebted for their help in many ways in the field and in the laboratory.

\section{RESUMO}

o presente trabalho baseia-se no estudo de um foco autóctone da doença de Chagas no municipio de Caxias, no Estado do Rio de Janeiro. O estudo incluiu a pesquisa de triatomíneos nos domicilios das localidades de Piranema, Amapá e Capivari, inquérito sorológico pelas reações de imuno-fluorescência e fixação do complemento para doença de Chagas na populaçốo dessas localidades e xenodiagnóstico dos casos com sorologia positiva e em animais diomésticos das residências onde foram encontrados triatomineos infectados.

De 115 casas pesquisadas na localidade de Piranema, 15 (13,0\%) estavam infestadas com Triatoma infestans. Nas demais localidades não foram encontrados triatomíneos. De um total de $1936 \mathrm{~T}$. infestans capturados, 146 estavam infectados com Trypanosoma cruzi.

Do ponto de vista epidemiológico é importante assinalar a adaptação do Triatoma infestans ao domicílio humano numa área com grande densidade de populaçâio na baixada fluminense, em municipio próximo ao litoral do Estado do Rio de Janeiro.

\section{REFERENCES}

1. ARAGÃO, M. B. and SOUZA, S. A. Triatoma infestans colonizando domicílios na baixada fluminense, Estado do Rio de Janeiro. Rev. Soc. Bras. Med. Trop., 5: 115-121, 1971.

2. BUSTAMANTE, F. M. and GUSMAOO, I. B. - Sobre um foco de Triatoma infestans nos municípios de Rezende e Itaverá, Estado do Rio de Janeiro. Rev. Bras. Mal. D. Trop., 5: 23-28, 1953.

3. COURA, J. R., TOSTA, C. E., VIEIRA, W., and FIGUEIREDO DE, N. - Um foco de doença de Chagas transmitida pelo Triatoma infestans na baixada fluminense, município de Caxias, Estado do Rio de Janeiro, Brasil Rev. Soc. Bras. Med. Trop., 5: 123-129, 1971.

4. DIAS, E., LARANJA, F. S., GUIMARAES, F. N. and BRANT, T. C. - EStudo preliminar de inquérito sorologico-electrocardiográfico em populaçôes não selectionadas de zonas não endêmicas de doenças de Chagas. Rev. Bras. Mal. D. Trop., 5: 205-210, 1953. 
5. LENT, H. - Transmissores da Moléstia de Chagas no Estado do Rio de Janeiro. Rev Flum Med, 6: 3-13, 1942.

6. NEIVA, A. - Presença em uma localidacie do Estado do Rio de um novo transmissor da "moléstia de Chagas" encontrado infecado em condiçóes naturais (Nota prévia). Brasil Med., 28 333-335, 1914.
7. NEIVA, A. and PINTO, C. F. - Dos reduvídeos hematófagos encontramos no Distrito Federal e Estado do Rio de Janeiro. Bras. Med., 37: 37-45, 1923.

8. PETANA. W. B. and COURA, J. R. Experimental studies on Trypanosoma (Schizotrypanum) cruzi strains isolated from man, from animals, and from triatomine bugs in Brazil. Rev. Soc. Bras. Med.Trop. 8: 315-323, 1974. 
Table 1 - Showing the number of nymphal stages and adult Triatoma infestans collected from infested house at Piranema

\begin{tabular}{|c|c|c|c|c|c|c|c|c|}
\hline \multirow{2}{*}{ House no. } & \multicolumn{5}{|c|}{$N \mathrm{Y} M \mathrm{PHS}$} & \multicolumn{2}{|c|}{ A D U L T S } & \multirow{2}{*}{ Total } \\
\hline & 1 st & 2nd & $3 r d$ & 4 th & 5 th & males & females & \\
\hline P-1 & 6 & 23 & 35 & 27 & 9 & 30 & 39 & 169 \\
\hline P-2 & 3 & 102 & 179 & 108 & 98 & 89 & 108 & 687 \\
\hline P-3 & 0 & 0 & 0 & 0 & 0 & 3 & 2 & 5 \\
\hline P-4 & 0 & 0 & 1 & 0 & 1 & $\mathbf{0}$ & 1 & 3 \\
\hline$P-5$ & 0 & 0 & 1 & 0 & 0 & 0 & 1 & 2 \\
\hline$P-6$ & 70 & 155 & 181 & 80 & 99 & 54 & 58 & 697 \\
\hline$P-10$ & 0 & 0 & 0 & 0 & 1 & 8 & 4 & 13 \\
\hline P-13 & 0 & 2 & 18 & 12 & 0 & 0 & 0 & 32 \\
\hline$P-15$ & 7 & 9 & 37 & 35 & 17 & 16 & 34 & 155 \\
\hline P-87 & 0 & 2 & 0 & 0 & 0 & 1 & 1 & 4 \\
\hline$P-\theta 2$ & 0 & 0 & 0 & 0 & 0 & 0 & 1 & 1 \\
\hline P-96 & 0 & 2 & 7 & 3 & 1 & 2 & 2 & 17 \\
\hline$P-97$ & 0 & 2 & 0 & 0 & 0 & 0 & 0 & 2 \\
\hline P-104 & 4 & 13 & 19 & 25 & 27 & 13 & 2,2 & 123 \\
\hline P-106 & 3 & 3 & 4 & 5 & 3 & 6 & 2 & 26 \\
\hline Total & 93 & 313 & 482 & 295 & 256 & 222 & 275 & 1,936 \\
\hline
\end{tabular}


Table 1 - Showing the number of nymphal stages and adult Triatoma infestans collected from infested house at Piranema

\begin{tabular}{|c|c|c|c|c|c|c|c|c|}
\hline \multirow{2}{*}{ House no. } & \multicolumn{5}{|c|}{$N Y M P H S$} & \multicolumn{2}{|c|}{ ADULTS } & \multirow{2}{*}{ Total } \\
\hline & 1 st & 2nd & $3 \mathrm{rd}$ & 4 th & 5 th & males & females & \\
\hline P-1 & 6 & 23 & 35 & 27 & 9 & 30 & 39 & 169 \\
\hline P-2 & 3 & 102 & 179 & 108 & 98 & 89 & 108 & 687 \\
\hline P-3 & 0 & 0 & 0 & 0 & 0 & 3 & 2 & 5 \\
\hline$P-4$ & 0 & 0 & 1 & 0 & 1 & 0 & 1 & 3 \\
\hline P-5 & 0 & 0 & 1 & 0 & 0 & 0 & 1 & 2 \\
\hline$P-6$ & 70 & 155 & 181 & 80 & 99 & 54 & 58 & 697 \\
\hline$P-10$ & 0 & 0 & 0 & 0 & 1 & 8 & 4 & 13 \\
\hline$F-13$ & 0 & 2 & 18 & 12 & 0 & $\mathbf{0}$ & $\mathbf{0}$ & 32 \\
\hline$P-15$ & 7 & 9 & 37 & 35 & 17 & 16 & 34 & 155 \\
\hline$P-87$ & 0 & 2 & 0 & 0 & 0 & 1 & 1 & 4 \\
\hline$P-\theta 2$ & 0 & 0 & 0 & 0 & 0 & 0 & 1 & 1 \\
\hline P-96 & 0 & 2 & 7 & 3 & 1 & 2 & 2 & 17 \\
\hline P-97 & 0 & 2. & 0 & 0 & 0 & 0 & 0 & 2 \\
\hline P-104 & 4 & 13 & 19 & 25 & 27 & 13 & 2.2 & 123 \\
\hline P-106 & 3 & 3 & 4 & 5 & 3 & 6 & 2 & 26 \\
\hline Total & 93 & 313 & 482 & 295 & 256 & 222 & 275 & 1,936 \\
\hline
\end{tabular}




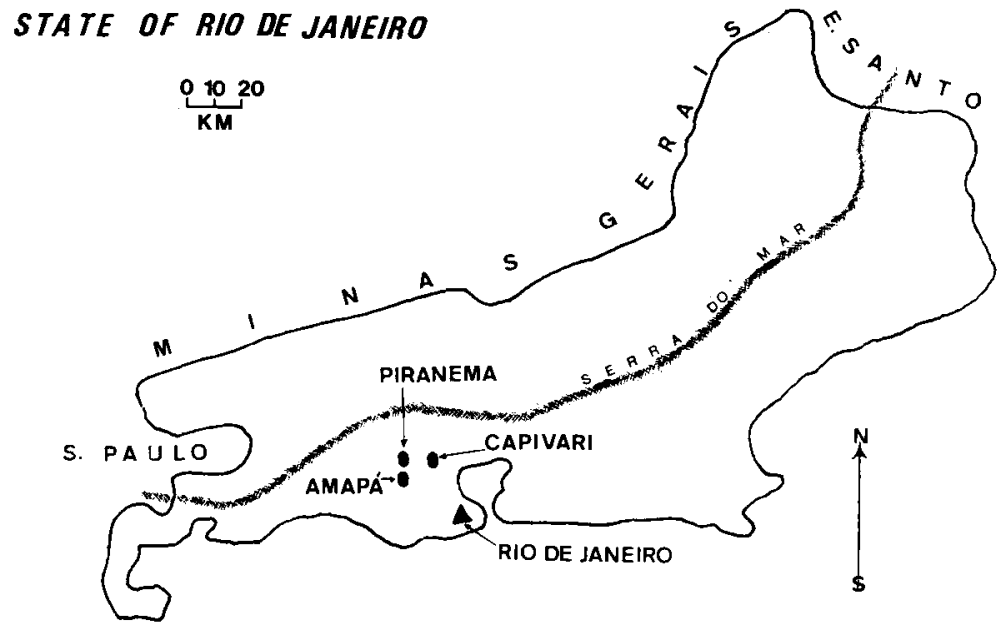

Fig. I - A map showing the Rio de Janeiro State and the localities investigated in the municipality of Caxias.

Table 2 - Showing the total number of nymphs and aciult Triatoma infesians captured in houses $\mathrm{P}-1, \mathrm{P}-3$ and $\mathrm{P}-15$, and the incidence of infection with $T$. cruzi in each developmental stage of the insects

\begin{tabular}{l|c|c|c|c|c|c|c|c}
\hline & \multicolumn{3}{c}{ N Y M P H S } & \multicolumn{2}{c|}{ A D U L T S } & \\
\hline & 1st & 2nd & 3rd & 4 th & 5 th & male & female & Total \\
\hline $\begin{array}{l}\text { Number of } \\
\text { bugs } \\
\text { captured }\end{array}$ & 13 & 34 & 73 & 61 & 26 & 49 & 75 & 329 \\
$\begin{array}{l}\text { Number } \\
\text { infected }\end{array}$ & 0 & 6 & 15 & 24 & 18 & 39 & 44 & 146 \\
\% Infected: & 0 & 17.6 & 20.8 & 39.3 & 62.2 & 79.5 & 58.6 & 44.3 \\
\hline
\end{tabular}




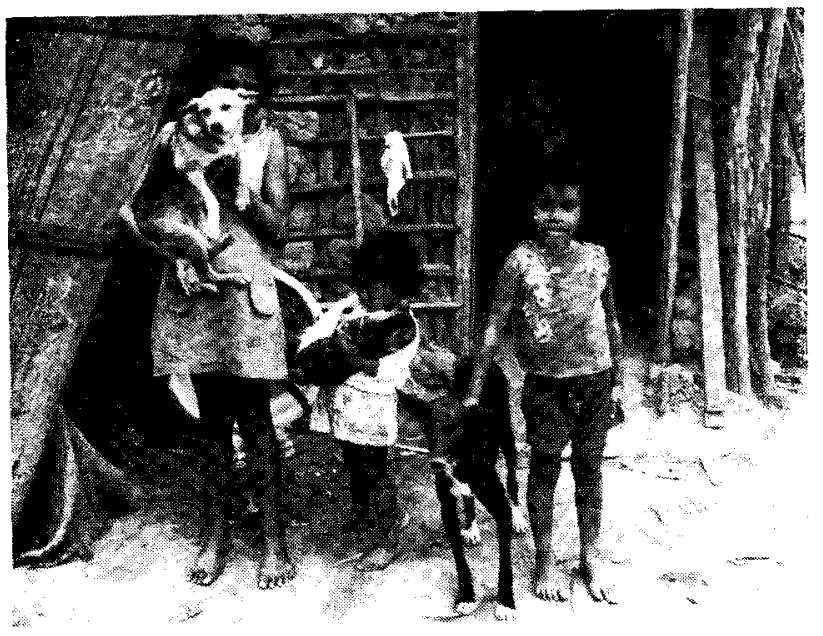

Fig. II-A - Three of the children from Piranema (house P-1) found serologically and parasitologically positive for Chagas' disease, and two dogs from the same household from which $T$.cruzi was recovered by xenodiagnosis.

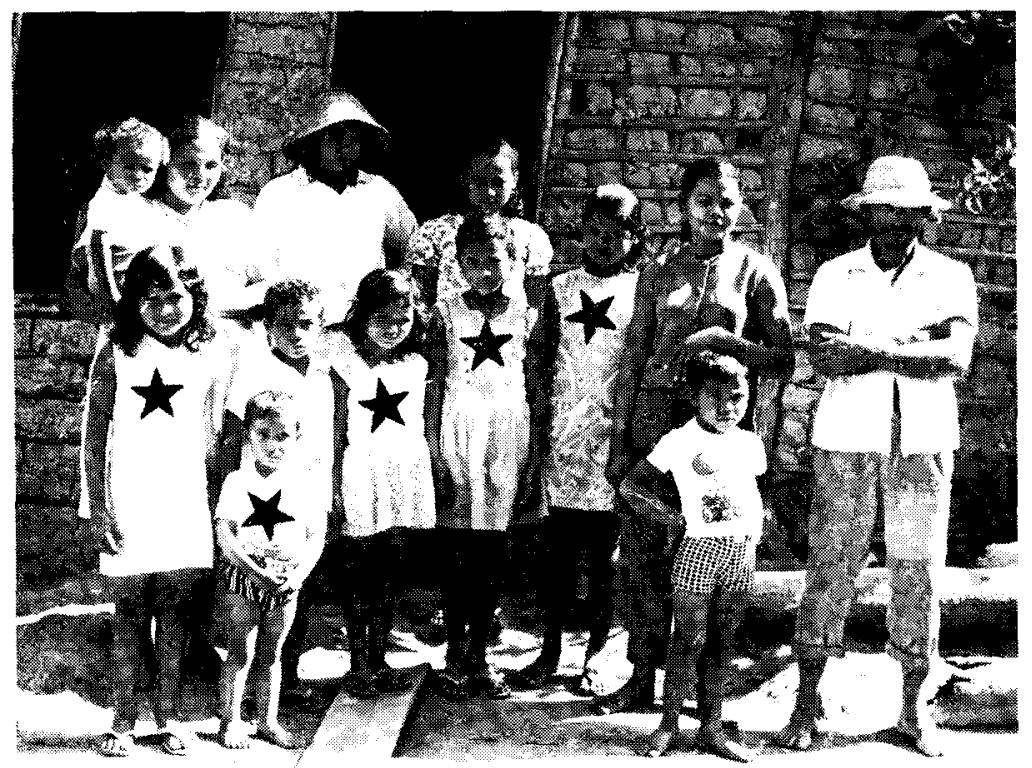

Fig. II-B - A family from Piranema in front of house P-15. The children marked with an asterisk were found serologically positive for Chagas' disease; four of these children had also a positive xenociagncsis test. 